Conference Circuit

\title{
Marketplace challenges for research libraries
}

\author{
By Gary Byrd
}

\section{The economics of knowledge management and resource sharing}

ב unding the national research information infrastructure in a political climate calling for greater privatization and marketplace solutions was the theme of the two-day "Challenging Marketplace Solutions to Problems in the Economics of Information" conference held in Washington, D.C., September 18-19, 1995. The conference was sponsored by the Council on Library Resources; the University at Albany, State University of New York (SUNY); the University Center Libraries of SUNY-Binghamton, Buffalo, and Stony Brook; the Association of Research Libraries; the Coalition for Networked Information; and the National Association of State Universities and Land-Grant Colleges. Over 200 attendees, including university presidents and other academic officers, librarians, computing professionals, economists, association and commercial publishers, and other interested faculty participated in eleven sessions featuring nearly
Association of Research Libraries (ARL), the Coalition for Networked Information, and the $\mathrm{Na}$ tional Association of State Universities and LandGrant Colleges. The conference sessions focused on the challenges of managing university investments in information technology, the economics of information resource sharing via the Internet, the costs and benefits of electronic journals and digital libraries, and knowledge management in a networked electronic environment.

\section{Integrating electronic resources into campus life}

Keynote speaker David P. Roselle, president of the University of Delaware, described that university's strategies for "weaving electronic resources into the fabric of campus life." These have included over 700 miles of campus network wiring, client-server computing, ubiquitous e-mail, and a variety of campus information systems designed to reduce paperwork and make life easier for all students, faculty, and staff. Roselle pointed to a combination of funding sources for these accomplishments: predict-

able state support, significant increases in research grants and private support, and the use of technologies to "do the same, or more, with less staff."

Mario Morino, president of the Morino Institute in Cleveland, challenged the attendees to "step out of the cocoon of higher education" and realize that the "unimaginable not only can but will happen." He described a future in which highspeed, high-bandwidth network communications have dramatically shifted the locus of information control from organizations (including libraries and publishers) to individual users, and where competition from the corporate sector may challenge the very survival of many 
research universities and their libraries. Citing Arthur Miller's Deatb of a Salesman, Morino warned that research libraries could become the "Willy Lomans of the Information Age."

\section{The economics of information}

The speakers and panelists throughout the conference included a large number of distinguished academic economists whose research is focused on the economics of information. Roger Noll from Stanford University discussed the economic role of basic research in U.S. universities, the high fixed costs of scholarly publications, and the difficulty of spreading those costs over a relatively small number of readers. Hal Varian, University of California at Berkeley, described the economic history of the Internet and various potential models for cost recovery by electronic publishers. Michael McPherson, Williams College, pointed out the many ironies and inefficiencies of the current marketplace for scholarly information: for example, university libraries buy fewer books, academic presses at the same institutions sell fewer books, while academic provosts struggle to allocate budget resources to these units and to the academic departments where faculty are encouraged to write and read increasing numbers of these books! Bruce Kingma, SUNY at Albany, reported on a recently completed SUNY study of interlibrary loan costs which suggests that, in the short term at least, providing access to materials in remote collections can provide research libraries with savings over local ownership. Finally, Malcolm Getz, Vanderbilt University, urged research libraries to look for ways to set prices for their information resources and services, since prices "empower users to vote with their dollars" and give libraries the marketplace signals needed to make more rational budget decisions.

\section{A new model for scientific communication}

One of the most widely discussed presentations during the conference was Richard Lucier's talk about the University of California-San Francisco's "knowledge management" model for scientific communication being developed as an alternative to the traditional system of acquiring biomedical books and journals or other information resources published elsewhere. This new model also includes a transition to the digital library with high-quality elec-
James O'Donnell compared the advent of the Internet to deregulation of the airlines in the 1970s; both transitions have been disruptive to old patterns. ...

tronic resources; personal communication tools to create, share, manipulate, store, and use information; and "effortless interfaces" for access to these resources. The UCSF library has launched an Internet publishing division called GalenuotPub to leverage the university's own intellectual property (such as the Tobacco Control Archives) for the benefit of the scientific community at large.

The conference included a host of other fascinating insights into the economic forces shaping higher education, research libraries, and scholarly communication. For example, Richard Rockwell from the Inter-university Consortium for Political and Social Research (ICPSR) at the University of Michigan described the pricing dilemmas facing member institutions when the Consortium can now distribute very large datasets like the American National Election Study (the oldest continuously running survey in the social sciences) on CD-ROM at very low marginal costs. The ICPSR faces a "serious free rider problem," said Rockwell, since institutions may not be willing to pay relatively high Consortium membership fees when its datasets can be readily copied and transmitted at little or no cost for researchers at nonmember institutions.

\section{No furning back}

James O'Donnell, editor of Bryn Mawr Classical Reviews, a highly subsidized electronic journal for humanities scholars published by the University of Pennsylvania, compared the advent of the Internet to deregulation of the airlines in the 1970s; both transitions have been disruptive to old patterns, both offer the possibility (but not a guarantee) of better service at lower cost, and, in both cases, there can be no turning back from the change momentum.

This review leaves out many other useful and important insights offered by the speakers and panelists. Fortunately, ARL will publish the complete proceedings, including many useful suggestions for acdditional research from the conference panelists. 


\section{INFORMATION COMES IN ALL SHAPES AND SIZES}

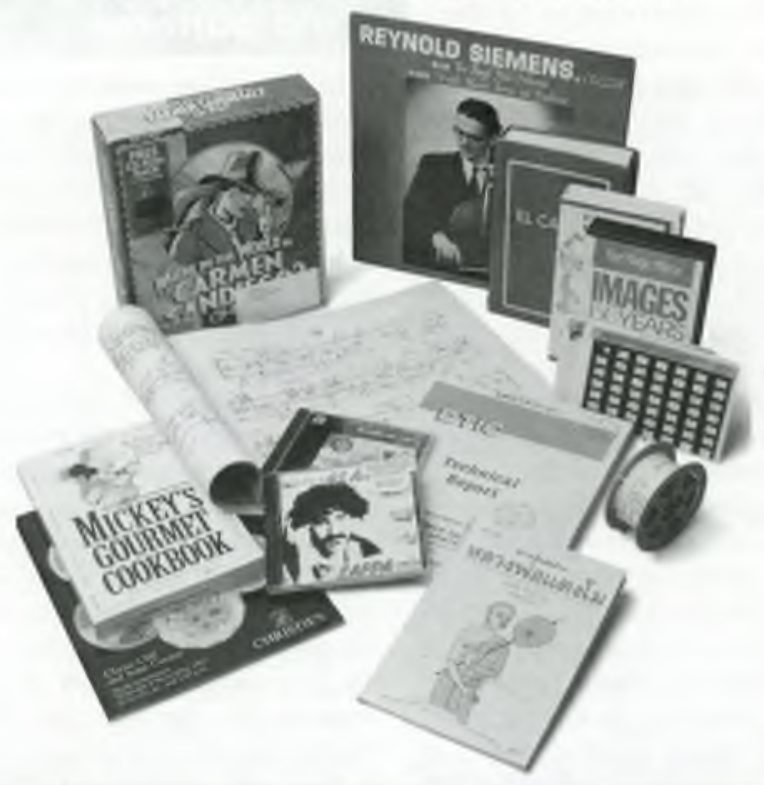

\section{OCLC's TECHPRO Service catalogs it all}

With library resources so stretched, it's challenging to keep your cataloging upto-date. And it's frustrating, because uncataloged materials are inaccessible to your patrons.

OCLC's TECHPRO Service can help. Since 1985, we've offered solutions for libraries that have cataloging backlogs or need ongoing cataloging support.

- Customized cataloging and physical processing to match your specifications

- Cataloging for all bibliographic formats and many languages

- Quality cataloging at prices that can reduce your overall cataloging costs

Contract cataloging for books, serials, scores, non-print items, foreign language materials and more-it's cataloging in all shapes and sizes-from OCLC's TECHPRO Service.

1.800-848.5878, ext. 4386 